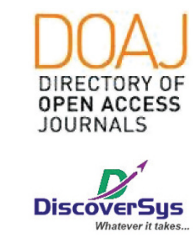

Published by DiscoverSys

\title{
Faktor risiko yang mempengaruhi length of stay pasien kanker solid dengan febrile neutropenia pasca kemoterapi neoadjuvant/terapeutik di Ruang Isolasi RSUP Sanglah, Bali
}

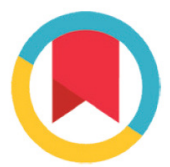

CrossMark

\author{
Ronald Natawidjaja ${ }^{1 *}$, Ida Bagus Tjakra Wibawa Manuaba², Putu Anda Tusta Adiputra²
}

\section{ABSTRACT}

Background: Febrile neutropenia is a common complication in patient undergoing chemotherapy. Length Of Stay (LOS) is an important marker for disease severity and use of medical resources in febrile neutropenia. This study was done to find the risk factor affecting length of stay in solid cancer patients with febrile neutropenia post neoadjuvant/therapeutic chemotherapy.

Method: This is a case control study without matching. Age $\geq 60$ years, (Absolute Neutrofil Count) ANC level $<1,5 \mu \mathrm{L}$, comorbid, $\mathrm{Hb}$ level $<10 \mathrm{gr} / \mathrm{dl}$, and albumin $<3 \mathrm{gr} / \mathrm{dl}$, were related to LOS ( $\leq 5$ days and $>5$ days). Univariate (chi square) and multivariate

(logistic regression) were used to analyse the statistic.

Results: Forty six patients met inclusion-exclusion criteria were included in this study. ANC level in all patients were $<1,5 \mu \mathrm{L}$ (100\%). Hb level $<10 \mathrm{gr} / \mathrm{dl}$ is statistically significant $(P<0.05)$, whereas age $\geq 60$ years, and comorbid, albumin level $<3 \mathrm{gr} / \mathrm{dl}$ were not is statistically significant $(P>0.05)$.

Conclusion: $\mathrm{Hb}$ level $<10 \mathrm{gr} / \mathrm{dl}$ is the risk factor for LOS $>5$ days in solid cancer patients with febrile neutropenia post neoadjuvant/ therapeutic chemotherapy.

Keywords: Length of Stay, Febrile Neutropenia, Risk Factor

Cite This Article: Natawidjaja, R., Manuaba, I.B.T.W., Adiputra, P.A.T. 2019. Faktor risiko yang mempengaruhi length of stay pasien kanker solid dengan febrile neutropenia pasca kemoterapi neoadjuvant/terapeutik di Ruang Isolasi RSUP Sanglah, Bali. Intisari Sains Medis 10 (1): 155-159. D0l: 10.1556/ism.v10i1.367

${ }^{1}$ Residen Bedah Umum, Fakultas Kedokteran Universitas Udayana, RSUP Sanglah, Bali, Indonesia

${ }^{2}$ Staf Pengajar Departemen Bedah Onkologi, Fakultas Kedokteran Universitas Udayana, RSUP Sanglah, Bali, Indonesia

\section{ABSTRAK}

Latar Belakang: Febrile neutropenia merupakan komplikasi yang cukup sering didapat pada pasien yang sedang menjalani kemoterapi. Length Of Stay (LOS) merupakan penanda penting untuk derajat keparahan penyakit dan pengeluaran biaya kesehatan pada febrile neutropenia. Penelitian ini dilakukan untuk mencari faktor risiko yang dapat mempengaruhi lama hari perawatan pada pasien kanker solid dengan febrile neutropenia pasca kemoterapi neoadjuvant/terapeutik.

Metode: Penelitian ini merupakan studi kasus kontrol tanpa matching. Usia $\geq 60$ tahun, Nilai Absolute Neutrofil Count (ANC) $<1,5 \mu \mathrm{L}$, komorbid, $\mathrm{Hb}<10 \mathrm{gr} / \mathrm{dl}$, dan albumin $<3 \mathrm{gr} / \mathrm{dl}$ dihubungkan dengan lamanya LOS ( $L O S \leq 5$ hari dan $>5$ hari). Analisis penelitian menggunakan analisis univariat (chi square) dan multivariat (regresi logistik) dengan SPSS versi 16.

Hasil: Sejumlah 46 pasien memenuhi kriteria inklusi-eksklusi pada studi ini. Nilai ANC pada seluruh sampel penelitian $<1,5 \mu \mathrm{L}(100 \%)$. Kadar $\mathrm{Hb}<10 \mathrm{gr} / \mathrm{dl}$ bermakna signifikan secara statistik $(\mathrm{P}<0,05)$, sedangkan faktor usia $\geq 60$ tahun, komorbid, dan albumin $<3 \mathrm{gr} /$ dl tidak berbeda bermakna $(P>0,05)$.

Kesimpulan: Kadar $\mathrm{Hb}<10 \mathrm{gr} / \mathrm{dl}$ merupakan faktor risiko lamanya LOS > 5 hari pada pasien kanker solid dengan febrile neutropenia paska kemoterapi neoadjuvant/terapeutik.

Kata Kunci: Length of Stay, Febrile Neutropenia, Faktor Risiko

Cite Pasal ini: Natawidjaja, R., Manuaba, I.B.T.W., Adiputra, P.A.T. 2019. Faktor risiko yang mempengaruhi length of stay pasien kanker solid dengan febrile neutropenia pasca kemoterapi neoadjuvant/terapeutik di Ruang Isolasi RSUP Sanglah, Bali. Intisari Sains Medis 10 (1): 155-159. D0l:10.1556/ism.v10i1.367

\section{PENDAHULUAN}

Peranan dokter spesialis bedah dalam penanganan kanker solid tidak sedikit. Pembedahan terhadap kanker solid terutama pada fase/ stadium awal merupakan modalitas utama terapi yang akan memberikan kesembuhan sampai lebih dari 65\% penderita. ${ }^{1}$ Dengan penambahan modalitas terapi lain seperti kemoterapi, maka angka kesembuhan dapat meningkat dan angka rekurensi dapat ditekan. 
Akan tetapi, kondisi di Indonesia tidaklah demikian. Sebagai contoh, data yang didapat dari Sub Bagian Onkologi FK UNUD/RSUP Sanglah Denpasar periode 2009-2010 mencatat bahwa $50 \%$ pasien kanker payudara datang sudah dalam stadium lanjut. ${ }^{2}$ Hal ini menyebabkan modalitas terapi kemoterapi menjadi peranan yang penting. Kemoterapi pada kanker solid dapat bersifat sebagai adjuvant, neoadjuvant, terapeutik maupun paliatif.

Kemoterapi sebagai modalitas terapi kanker solid tidak terlepas dari efeksamping yang ada. Darisekian banyak efek samping yang ada, febrile neutropenia merupakan komplikasi yang cukup sering didapat pada pasien yang sedang menjalani kemoterapi. Efek mielosupresif dari kemoterapi dapat menekan produksi dari sel darah putih khususnya neutrofil sehingga meningkatkan risiko terkena infeksi yang berat dan membutuhkan perawatan rumah sakit untuk pemberian antibiotik spektrum luas dan perawatan lain untuk meminimalisir morbiditas dan mortalitas. ${ }^{3}$ Weycker et al. menyebutkan $13.1 \%$ hingga $20.6 \%$ penderita kanker paska kemoterapi akan mengalami febrile neutropenia, dimana $89 \%$ hingga $94 \%$ penderita memerlukan tindakan rawat inap. ${ }^{3}$ Di RSUP Sanglah Denpasar sendiri, sejak Bulan Januari 2016 hingga bulan Agustus 2017 tercatat sebanyak 54 penderita febrile neutropenia paska kemoterapi yang menjalani perawatan di ruangan isolasi neutropenia.

Lama hari perawatan / Length Of Stay (LOS) merupakan penanda penting untuk derajat keparahan penyakit dan pengeluaran biaya kesehatan pada febrile neutropenia. Pasien kanker dengan febrile neutropenia yang memiliki lama hari perawatan yang panjang memiliki risiko timbulnya terkenanya infeksi multi-drug-resistant (MDR) dan menghambat jadwal kemoterapi pasien. ${ }^{3}$ Hal ini berdampak balik terhadap hasil/ outcome dari terapi kemoterapi. Lebih lanjut, obat, biaya, dan tenaga kesehatan yang dikeluarkan untuk hal tersebut tidaklah sedikit. Di Amerika, biaya ratarata yang harus dikeluarkan untuk penanganan pasien kanker dengan febrile neutropenia berkisar \$16.291 hingga \$19.456 US. ${ }^{3,4}$

Adanya pemahaman mengenai faktor apa saja yang dapat mempengaruhi lama hari perawatan pasien dengan febrile neutropenia pasca kemoterapi membuat para klinisi dapat mendeteksi dini dan melakukan intervensi dini yang selektif, sehingga dapat menurunkan biaya kesehatan dan meningkatkan kualitas hidup penderita kanker. Pada penelitian ini, peneliti ingin mencari faktorfaktor apa saja yang dapat mempengaruhi lama hari perawatan pada pasien kanker solid dengan febrile neutropenia pasca kemoterapi neoadjuvant/ terapeutik yang dirawat diruang perawatan isolasi neutropenia RSUP Sanglah, Denpasar-Bali.

\section{METODE PENELITIAN}

Penelitian ini merupakan studi kasus kontrol tanpa matching. Data penelitian diambil secara retrospektif sejak Januari 2016 hingga November 2017. Populasi penelitian ini adalah semua penderita kanker solid dengan febrile neutropenia pasca kemoterapi neoadjuvant/ terapeutik. Populasi terjangkau adalah semua pasien kanker solid dengan febrile neutropenia pasca kemoterapi neoadjuvant/ terapeutik yang dirawat di ruang perawatan isolasi neutropenia RSUP Sanglah Denpasar dimulai sejak tahun Januari 2016 hingga November 2017. Sampel penelitian adalah semua populasi terjangkau yang memenuhi kriteria penerimaan. Sampel diambil secara konsekutif (Consecutive sampling).

Kriteria inklusi penelitian ini adalah penderita kanker solid dengan febrile neutropenia yang mendapat perawatan di ruang isolasi Bakung Barat RSUP Sanglah. Kanker solid yang termasuk dalam penelitian ini adalah: kanker payudara, kanker kelenjar tiroid dan paratiroid, kanker kelenjar salivarius, kanker rongga mulut, kanker kulit baik melanoma maligna maupun non melanoma, sarkoma jaringan lunak, kanker gastrointestinal, kanker hati, kanker empedu, dan kanker pankreas. Selain itu penderita tidak terbukti infeksi dari rontgen thoraks dan pemeriksaan fisik awal, dirawat khusus untuk mengatasi febrile neutropenia, tanpa gangguan kesadaran saat dirawat, Karnofksy Score pasien $\geq 70$, kemoterapi yang digunakan bersifat neoadjuvant/ terapeutik, serta dosis kemoterapi sesuai standar (bukan high dose kemoterapi).

Kriteria Eksklusi penelitian ini adalah penderita meninggal saat dirawat, demam tanpa neutropenia, penderita kanker solid dengan febrile neutropenia tanpa riwayat kemoterapi sebelumnya, penderita dengan gangguan kesadaran saat dirawat, penderita dengan Retinoblastoma, keganasan dari otak dan sistem saraf pusat, keganasan bidang ginekologi (kanker rahim, cerviks, dan ovarium), keganasan hematologi, limfoma, penderita dengan Karnofsky score $<70$, penderita dengan end of life care, penderita dengan kemoterapi adjuvant atau kemoterapi paliatif.

Dari data yang terkumpul, data selanjutnya diolah secara deskriptif untuk mengetahui karakteristik data. Data kemudian dimasukkan dalam tabel 2x2 dan dianalisis menggunakan SPSS 16 for Windows untuk mengetahui hubungan faktor risiko (Odds Ratio). Analisis statistik akan dilakukan analisis univariat untuk masing-masing faktor risiko dan kemudian dilakukan analisis multivariat dengan regresi logistik mengingat variabel tergantungnya berskala nominal dikotom (LOS $\leq 5$ hari dan LOS $>5$ hari). 


\section{HASIL PENELITIAN}

Selama rentang waktu Januari 2016 - November 2017, tercatat 117 pasien dengan febrile neutropenia di ruang isolasi neutropenia RSUP Sanglah (Bakung Barat). Sejumlah 46 pasien memenuhi kriteria inklusi-eksklusi dalam penelitian ini.

Analisis statistik pada penelitian ini menggunakan uji hipotesis variabel kategorik tidak berpasangan (tabel 2x2). Uji yang digunakan adalah uji chi-square bila memenuhi syarat. Bila tidak

Tabel 1. Karakteristik demografis responden penelitian

\begin{tabular}{lc}
\hline \multicolumn{1}{c}{ Parameter } & $\mathbf{N}(\%)$ \\
\hline Jenis Kelamin & \\
Laki-Laki & $8(17,4)$ \\
Perempuan & $38(82,6)$ \\
Lama rawat inap (LOS)(Hari) & \\
LOS $>5$ hari & $25(54,3)$ \\
LOS $<5$ hari & $21(45,7)$ \\
Usia (Tahun) & \\
$\geq 60$ tahun & $5(10,9)$ \\
$<60$ tahun & $41(89,1)$ \\
Hemoglobin (mg/dL) & $21(45,7)$ \\
Hb $<10$ & $25(54,3)$ \\
Hb $\geq 10$ & \\
Albumin (mg/dL) & $9(19,6)$ \\
Albumin $<3$ & $37(80,4)$ \\
Albumin $\geq 3$ & \\
Komorbid & $8(17,4)$ \\
Positif & $38(82,6)$ \\
Negatif & \\
Absolute Neutrophil Count (ANC) & $46(100,0)$ \\
ANC $<1,5$ & $0(0,0)$ \\
ANC $\geq 1,5$ &
\end{tabular}

Tabel 2. Analisis faktor resiko terhadap lama rawat inap (LOS)

\begin{tabular}{|c|c|c|c|c|c|}
\hline \multirow{2}{*}{ Variabel } & \multicolumn{2}{|c|}{ Kelompok } & \multirow[b]{2}{*}{$\mathbf{P}$} & \multirow[b]{2}{*}{ OR } & \multirow{2}{*}{ 95\% IK } \\
\hline & $\operatorname{LOS}>5$ & $\leq 5$ hari & & & \\
\hline \multicolumn{6}{|l|}{ Usia (Tahun) } \\
\hline$\geq 60$ tahun & 4 & 1 & $0,357^{* *}$ & 3,8 & $0,39-37,07$ \\
\hline$<60$ tahun & 20 & 21 & & & \\
\hline \multicolumn{6}{|c|}{ Hemoglobin (mg/dL) } \\
\hline $\mathrm{Hb}<10$ & 15 & 6 & $0,033^{*}$ & 3,75 & $1,08-12,95$ \\
\hline $\mathrm{Hb} \geq 10$ & 10 & 15 & & & \\
\hline \multicolumn{6}{|l|}{ Albumin (mg/dL) } \\
\hline Albumin $<3$ & 7 & 2 & 0,151 & 3,69 & $0,67-20,19$ \\
\hline Albumin $\geq 3$ & 18 & 19 & & & \\
\hline \multicolumn{6}{|c|}{ Absolute Neutrophil } \\
\hline \multicolumn{6}{|c|}{ Count (ANC) } \\
\hline ANC $<1,5$ & 25 & 21 & - & - & - \\
\hline $\mathrm{ANC} \geq 1,5$ & 0 & 0 & & & \\
\hline \multicolumn{6}{|l|}{ Komorbid } \\
\hline Positif & 5 & 4 & $0,71^{* *}$ & 1,06 & $0,24-4,59$ \\
\hline Negatif & 20 & 17 & & & \\
\hline
\end{tabular}

P: bermakna apabila < 0,05; LOS: Length of Stay; OR: Odds Ratio; IK: Interval Kepercayaan; *Chi-square, **Fisher Exact. memenuhi syarat uji chi-square, digunakan uji alternatifnya yaitu uji Fisher Exact (Tabel 2).

Analisis statisik berdasarkan tabel $2 \times 2$ menunjukkan bahwa kadar $\mathrm{Hb}$ memiliki nilai $\mathrm{p}<$ 0.05 ( $p=0.033$, OR 3.75, CI $1.08-12.95)$. Hipotesis $\mathrm{HO}$ ditolak. Kadar Hb secara statistik signifikan sebagai faktor risiko terhadap lamanya LOS pasien.

Berbeda hal dengan kadar Usia, kadar Alb, dan faktor Komorbid. Analisis statistik menunjukkan nilai $\mathrm{p}>0,05$ (Usia: $p=0.357$, OR 3.80 , CI 0.39 37.07; Kadar Alb: $p=0.151$, OR 3.69, CI 0.67-20.19; Komorbid: $p=0.71$, OR 1.06, CI $0.24-4.59$ ). Hipotesis H0 diterima. Usia, Kadar Alb, dan faktor komorbid secara statistik bukan merupakan faktor risiko lamanya LOS pasien. Kadar ANC pada penelitian ini tidak dilakukan analisis statistik mengingat hasil seluruh sampel yang ada menunjukkan kadar ANC $<1.5$ baik kelompok kasus maupun kelompok kontrol.

Pada analisis multivariat didapatkan percentage correct untuk keseluruhan adalah $71.7 \%$, yang menunjukkan data fit dengan model regresi logistik karena percentage correct $>50 \%$. Dari uji Goodness of fit dari Hosmer-Lemeshow didapatkan nilai Chi-square $=2.113$ dengan nilai $\mathrm{p}=0.715$. Hasil analisis regresi logistik menunjukkan bahwa kadar $\mathrm{Hb}$ secara signifikan mempengaruhi LOS. Hasil ini sejalan dengan analisis bivariat sebelumnya yang menunjukkan bahwa kadar $\mathrm{Hb}$ secara signifikan mempengaruhi LOS.

\section{PEMBAHASAN}

Penatalaksanaan penderita kanker pada stadium lanjut bertujuan untuk mengurangi ukuran tumor yang unresectable, memperbaiki kontrol lokal, dan mengurangi penyebaran metastasis dengan cara pemberian kemoterapi neoadjuvant. ${ }^{1,5}$ Saat ini pemberian kemoterapi bersifat multi-drug therapy. Hal ini disebabkan suatu kanker merupakan kanker yang heterogen, artinya memiliki bentuk sel dan sifat sel yang beraneka ragam, termasuk dalam hal resistensi dan sensitifitas terhadap obat kemoterapi yang juga berbeda. ${ }^{5}$

Adanya keterbatasan dimana obat kemoterapi yang tidak dapat membedakan antara sel normal dan sel kanker, menyebabkan efek negatif pada sel-sel normal terutama pada sel-sel yang aktif berproliferasi/ mitosis, seperti sel-sel darah. Sel darah yang memiliki umur terpendek akan mengalami "penia" terlebih dahulu. Dalam hal ini adalah leukosit, terutama neutrofil, diikuti trombosit dan eritrosit.

Faktor risiko umum untuk terjadinya neutropenia dapat dikelompokan menjadi empat, yakni akibat terapi yang diperoleh, faktor pasien itu sendiri, jenis kanker yang diderita, dan komorbid 
yang ada. Faktor usia, gizi buruk, adanya komorbid serta kondisi anemia merupakan faktor risiko yang telah banyak diteliti sebelumnya dan memiliki dampak yang signifikan.

Risiko febrile neutropenia timbul ketika risiko infeksi mulai muncul, yaitu saat nilai ANC kurang dari $1000 / \mu \mathrm{L}$ dan meningkat secara dramatis saat ANC kurang dari 500/ $\mu$ L. Kurang dari setengah pasien neutropenia yang menjadi febrile neutropenia berhasil ditemukan sumber infeksi dan sisanya ( $>50 \%$ ) masuk dalam fever of unknown origin (FUO). ${ }^{6} 10-20 \%$ pasien dengan ANC kurang dari $100 / \mu \mathrm{L}$ akan terjadi bakteremia. ${ }^{6,7}$ Hal ini sesuai dengan hasil penelitian dimana dari seluruh sampel yang ada (46 sampel) memiliki kadar ANC $<1,5 / \mu \mathrm{L}$, dimana 45 sampel (98\% sampel) memiliki kadar ANC kurang dari 1000/ $\mu \mathrm{L}$.

Hospital length of stay (LOS) merupakan marker yang penting untuk menilai derajat keparahan dan penggunaan sumber daya dalam konteks perawatan penderita febrile neutropenia. ${ }^{4}$ Prosedur diagnosis dan terapi yang diberikan pada penderita febrile neutropenia seringkali dihubungkan dengan besarnya pengeluaran finansial dan prolonged LOS memiliki dampak negatif pada finansial dan sumber daya kesehatan. ${ }^{8,9} \mathrm{Di}$ Indonesia dengan adanya sistem pembayaran BPJS saat ini, menuntut tenaga kesehatan untuk semakin efisien dalam penggunaan sumber daya baik sarana maupun prasarana yang tersedia. LOS yang lama berhubungan erat dengan meningkatnya biaya dan sumber daya yang digunakan.

Dari kelima faktor risiko yang diteliti pada penelitian ini (selain kadar ANC) menunjukkan bahwa Usia $\geq 60$ thn, kadar albumin $<3 \mathrm{gr} / \mathrm{dl}$, kadar $\mathrm{Hb}<10 \mathrm{gr} / \mathrm{dl}$ lebih sering didapatkan pada kelompok kasus, namun hanya faktor kadar $\mathrm{Hb}$ yang signifikan secara statisik merupakan faktor risiko lamanya LOS pasien febrile neutropenia pada kasus paska kemoterapi. Hal ini sejalan dengan penelitian Silber yang memperlihatkan kadar hemoglobin yang rendah merupakan prediktor komplikasi neutropenia. ${ }^{10}$ Selain itu, adanya faktor eksternal seperti lamanya menunggu ketersediaan darah dari PMI untuk transfusi memberikan sumbangsih lamanya LOS pasien febrile neutropenia dengan anemia yang memerlukan perbaikan kadar $\mathrm{Hb}$. Penelitian lain juga menunjukkan bahwa kadar $\mathrm{Hb}$ yang rendah merupakan prediktor terjadinya neutropenia berat, yang meningkatkan risiko terjadinya komplikasi febrile neutropenia dan infeksi. ${ }^{11,12}$

Penelitian-penelitian sebelumnya menemukan bahwa usia lanjut merupakan faktor risiko untuk terjadinya neutropenia berat. ${ }^{11-14}$ Selain itu, pada penderita usia tua berhubungan dengan immunosenescene dimana terjadi remodelling dari sistem imun dengan penurunan kemampuan sel-sel imun untuk merespon stimulus dan peningkatan respon terhadap tolerogenik signals. Akan tetapi penelitian lain menunjukkan tidak ditemukan adanya korelasi bertambahnya risiko neutropenia dengan bertambahnya usia setelah 65 tahun. $^{11}$ Penelitian lain yang dilakukan oleh Saleem \& Zahid menunjukkan nilai yang tidak signifikan antara usia $\leq 60$ tahun dengan usia > 60 tahun untuk terjadinya febrile neutropenia. ${ }^{15}$ Mungkin hal ini dikarenakan pada pasien usia lanjut dosis pemberian kemoterapi lebih rendah atau pemberian kemoterapi pada penderita usia lanjut kurang agresif. Selain itu, pasien usia lanjut umumnya membutuhkan bantuan orang lain dalam menjalani aktifitas kehidupan kesehariannya, yang berdampak pada berkurangnya skor Karnofski < 70 , sehingga pasien tidak masuk dalam kandidat pilihan kemoterapi dimana umumnya syarat kemoterapi membutuhkan skor Karnofski $\geq 70$.

Penelitian lain menunjukkan bahwa adanya status nutrisi yang buruk menyebabkan performa status yang buruk, merupakan faktor risiko yang signifikan untuk terjadinya CIN..$^{10,13,16}$ Status nutrisi yang buruk erat hubungannya dengan kadar albumin darah. Pada penelitian ini, tidak didapatkan hasil yang signifikan secara statistik antara kelompok kasus dan kelompok kontrol. Hal ini dimungkinkan karena pada status nutrisi yang buruk, menyebabkan pasien jatuh kedalam skor Karnofski $<70$, yang menyebabkan pasien tidak layak untuk menjalani kemoterapi (perbaikan kondisi) serta pasien tereksklusi dari penelitian ini. Selain itu, jumlah sampel yang sedikit dapat mempengaruhi hasil dari penelitian ini.

Penelitian-penelitian lainnya menunjukkan bahwa adanya komorbiditas pada pasien kanker akan menambar risiko neutropenia dan komplikasi yang serius. ${ }^{17-20}$ Hasil penelitian ini menunjukkan hasil statistik yang tidak bermakna antara kelompok kasus dan kontrol. Hal tersebut mungkin disebabkan karena adanya komorbid yang "terkontrol" dari pasien menyebabkan kondisi fisik pasien lebih baik dengan skor Karnofski $\geq 70$. Sedangkan untuk pasien dengan komorbiditas yang "tidak terkontrol", menyebabkan kondisi pasien masuk dengan skor Karnofski pasien $<70$. Pada penelitian ini, pasien tereksklusi serta pasien tidak layak untuk menjalani kemoterapi.

\section{KESIMPULAN}

Kadar $\mathrm{Hb}<10 \mathrm{gr} / \mathrm{dl}$ merupakan faktor risiko lamanya LOS > 5 hari pada pasien kanker solid dengan febrile neutropenia paska kemoterapi neoadjuvant/terapeutik. Usia $\geq 60$ tahun, kadar 
albumin $<3 \mathrm{dr} / \mathrm{dl}$, adanya komorbid, serta kadar ANC $<1.5 \mu \mathrm{L}$ bukan merupakan faktor risiko lamanya LOS > 5 hari pada pasien kanker solid dengan febrile neutropenia paska kemoterapi neoadjuvant/terapeutik.

\section{DAFTAR PUSTAKA}

1. Mohamed I. Carcinoma of the Breast. In: Skeel RT (ed) Handbook of Cancer Chemotherapy. 7th ed. Philadelpia: Lippincott Williams \& Wilkins. 2007: 298-321.

2. Yarso K, Sudarsa I, Wibawa-Manuaba I. Clinical Initial Response of Neoadjuvant Chemotheraphy in Triple Negative, HER-2, and Luminal Types of Breast Cancer in Denpasar (A Preliminary Study). Bali Medical Journal. 2012; 1(1):12-16

3. Weycker D, Li X, Edelsberg J, Barron R, Kartashov A, $\mathrm{Xu}$ H., Lyman G.H. 2015. Risk and Consequences of Chemotherapy-Induced Febrile Neutropenia in Patients With Metastatic Solid Tumors. American Society of Clinical Oncology: Journal of Oncology Practice. 2015; 11(1): 47-56.

4. Dulisse B, Li SX, Gayle JA, Barron RL, Ernst FR, Rothman KJ, Legg JC, Kaye JA.. A retrospective study of the clinical and economic burden during hospitalizations among cancer patients with febrile neutropenia. J Med Econ. 2013; 16(6): 720-735.

5. Summerhayes M, Daniel S. Practical Chemotherapy. Bristol: Radchiffe Medical Press. 2003: 45-65.

6. Schimpff SC. Empiric antibiotic therapy for granulocytopenic patients. Bull N Y Acad Med. 1982; 58(8): 750-756.

7. Bodey GP, Buckley M, Sathe YS, Freireich EJ. Quantitative relationships between circulating leucocytes and infection in patients with acute leukemia. Ann Intern Med. 1966; 64(2):328-340

8. Schilling MB, Parks C, Deeter RG. Costs and outcomes associated with hospitalized cancer patients with neutropenic complications: A retrospective study. Exp Ther Med. 2011; 2(5): 859-866.

9. Zhou YP, Jin J, Ding Y, Chee YL, Koh LP, Chng WJ, Chan DS, Hsu LY. Direct costs associated with febrile neutropenia in inpatients with hematological diseases in Singapore. Support Care Cancer. 2014; 22(6):1447-51.

10. Silber JH. Fridman M, DiPaola RS, Erder MH, Pauly MV, Fox KR. First-cycle blood count and subsequent neutropenia, dose reduction, or delay in early-stage breast cancer therapy. J Clin Oncol. 1998; 16(7): 2392-2400.

11. Lyman GH, Morrison VA, Dale DC, Crawford J, Delgado DJ, Fridman M; OPPS Working Group; ANC Study
Group.. Risk of Febrile Neutropenia among Patients with Intermediate-Grade Non-Hodgkin's Lymphoma Receiving CHOP Chemotherapy. Leuk Lymphoma. 2003; 44(12):2069-276.

12. Morrison V.A., Caggiano V., Fridman M. A Model to Predict Chemotherapy-Related Severe or Febrile Neutropenia in Cycle One among Breast Cancer and Lymphoma Patients. Proc Am Soc Clin Oncol, 2004; 23:742.

13. Kloess M, Wunderlich A, Trumper L. Predicting hematotoxicity in multicycle chemotherapy. Blood. 1999; 94 (suppl 1):87a.

14. Aslani A, Smith RC, Allen BJ, Pavlakis N, Levi JA.. The Predictive Value of Body Protein for ChemotherapyInduced Toxicity. Cancer. 2000; 88(4): 796-803

15. Saleem L, Zahid NA. Is Serum Albumin an Independent Predictor of Post Chemotherapy Febrile Neutropenia? Pak Armed Forces Med J: Pakistan. 2017; 67(5):768-74

16. Voog E, Bienvenu J, Warzocha K, Moullet I, Dumontet C, Thieblemont C, Monneret G, Gutowski MC, Coiffier B, Salles G.Factors that predict chemotherapy-induced myelosuppresion in lymhoma patients: role of the tumor necrosis factor ligand-receptor system. J Clin Oncol. 2000; 18(2):325-31.

17. Gonzalez-Barca E, Sevilla AF, Carratala J, Salar A, Peris J, Grañena A, Gudiol F. Prognostic factor influencing mortality in cancer patients with neutropenia and bacteremia. Eur J Clin Microbiol Infect Dis. 1999; 18(8):539-44.

18. Kuderer N, Cosler LE, Crawford J, Dale DC, Lyman GH. Cost and mortality associated with febrile neutropenia in adult patients. Proc Am Soc Clin Oncol. 2002; 21:250.

19. Klastersky J, Paesmans M, Rubenstein EB, Boyer M, Elting L, Feld R, Gallagher J, Herrstedt J, Rapoport B, Rolston $\mathrm{K}$, Talcott J.. The multinational association for supportive care in cancer risk index: a multinational scoring system for identifying low risk febrile neutropenic cancer patients. J Clin Oncol. 2000; 18(16):3038-3051.

20. Prabawa IPY, Bhargah A, Liwang F, Tandio DA, Tandio AL, Lestari AAW, Budiana ING, Manuaba IBAP. Pretreatment Neutrophil-to-Lymphocyte ratio (NLR) and Plateletto-Lymphocyte Ratio (PLR) as a Predictive Value of Hematological Markers in Cervical Cancer. Asian Pacific Journal of Cancer Prevention. 2019; 20(3).

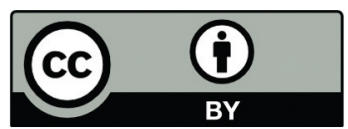

This work is licensed under a Creative Commons Attribution 